\title{
The Multifunctional Role of Shelterbelts in Intensively Managed Agricultural Land - Silvoarable Agroforestry in Hungary
}

\author{
Nóra SZIGETI $^{\mathrm{a}^{*}}-$ Norbert FRANK $^{\mathrm{b}}-$ Andrea VITYI $^{\mathrm{a}}$ \\ ${ }^{a}$ Institute of Forest and Environmental Techniques, University of Sopron, Sopron, Hungary \\ ${ }^{b}$ Institute of Silviculture and Forest Preservation, University of Sopron, Sopron, Hungary
}

\begin{abstract}
The use of shelterbelts as windbreaks to protect and increase field productivity has a long history in Hungary. Nevertheless, when shelterbelts began to wane, many environmental problems such as soil drying, deflation, and erosion began to occur, which in turn led to economic difficulties. Earlier field experience supported by new results indicates that shelterbelts are beneficial for intensively-treated fields, this despite the space shelterbelts require. Our research study aims to summarize the information available in Hungarian and international literature regarding the most effective shelterbelt structure. In addition, the study supports the design of multipurpose tree plantations with recommendations to mitigate climate change impacts and minimize the negative effects of intensive agricultural technology. In this article we would like to draw attention to the fact that shelterbelts can serve as effective tools in agroforestry and can be regarded as a means of ensuring economically and environmentally sustainable methods for agriculture. Below, we summarize how shelterbelts can help with adaptation to coming global and local challenges; we also describe why and how shelterbelts can be renewed and implemented in a reasonable way.
\end{abstract}

shelterbelt / productivity / green infrastructure

Kivonat - Az erdősávok szerepe intenzíven müvelt mezőgazdasági területeken - szántóföldi agrárerdészet Magyarországon. Egyes európai országokban komoly hagyományokkal rendelkezik a mezővédő erdősávok telepítése az épített környezet, a szántóföldek védelme, a termelékenység növelése érdekében, a szélerősség csökkentése és a klíma szabályzása által. Ahol ezeket az erdősávokat felszámolták, komoly környezeti problémák merültek fel, mint például erózió, a talaj kiszáradása, defláció, amelyek gazdálkodási nehézségeket okoznak. A korábbi szakirodalom és jelenlegi európai kutatási eredmények alapján úgy tủnik, a területfoglalással együttvéve is előnyösek az erdősávok az intenzíven mủvelt területeken. Kutatásunk célja, hogy a magyar és nemzetközi szakirodalom alapján összefoglaljuk a mezővédő erdősávok leghatékonyabb felépítéséről rendelkezésre álló információkat, és ajánlásokkal támogassuk a többcélú erdősáv rendszerek tervezését a klímaváltozáshoz való alkalmazkodás és az intenzív mezőgazdasági technológiák kedvezőtlen hatásainak csökkentése érdekében.

erdősáv / termelékenység / zöld infrastruktúra

\footnotetext{
*Corresponding author: szigeti.nora@uni-sopron.hu; H-9400 SOPRON, Bajcsy-Zs. u. 4, Hungary
} 


\section{INTRODUCTION}

Extreme weather, droughts, and the increased frequency of flooding have negative impacts on natural vegetation as well as the quantitative and qualitative parameters and safety of agricultural production (Akpoti et al. 2019, Luetzenburg et al. 2019, Wiréhn 2018). Erosion, pollution, snowdrift, frost, and drought can all cause problems for infrastructural facilities (e.g. roads), and for quality of life as well. (Echavarren et al. 2019, Khavarian-Garmsir 2019). Natural or anthropogenic impacts can be reduced through technological solutions, but living plant organisms may replace these or increase their efficiency when biologically active areas are developing, which can favourably affect the quality of the environment (e.g. protecting species and soils, climate conditioning.) Targeted usage of appropriately planted vegetation (including non-forest plantations ${ }^{1}$ as well) can significantly contribute to the supportable execution of ecological needs, and the requirements of environmental management and nature protection. In that way, the development of shelterbelt systems could strongly contribute to the EU Strategy on Green Infrastructures (GIs), which promotes the deployment of GIs across Europe (EC 2013).

The first shelterbelt data in Hungary is connected to a windbreak established in 1802 . The aim of planting 10 rows of willow trees was to settle drifting sand and facilitate agricultural production (Danszky 1972). The first purposeful establishment of forests were in the 1950s, which resulted in the shelterbelts reaching their maximum length in Hungary in this period (Négyesi 2018). Agricultural techniques developed by leaps and bounds until the 1970s, causing a demand for large-scale farming. This in turn led to a decrease in shelterbelts as the space reserved for them were absorbed into farming (Takács - Frank 2008). In addition to this, shelterbelt ownership became unclear after communism ended; therefore, many remaining plantations were simply abandoned. Nowadays, the common European Union agricultural policy supports establishment of shelterbelts, and they are intensively researched alongside economic interests and ecosystem services.

The significance of this study is that it evaluates the effects of shelterbelts in a multifunctional way based on the results of studies from different perspectives accumulated over decades. The collected data indicates that, aside from their land requirements, the most significant disadvantage of shelterbelts is the decrease in yield caused by competition. A properly planned and planted shelterbelt comprises a very small portion of agricultural land, and its advantages are many times greater than its disadvantages (Mize et al. 2008). Moreover, root pruning effectively reduces the competition with the crop (Kort 1988, Kowalchuk et al. 1995).

\section{THE EXTENT OF SHELTERBELT SYSTEMS IN EUROPE}

Hedgerows and shelterbelts are grouped together as windbreak tree plantations in European surveys and project reports; therefore, separate data for each is currently unavailable. These agricultural protection plantations in some European countries are examples of the integration of trees with farming systems. Herzog (2000) defines hedgerows as structures comprised of trees or bushes that separate land parcels of different owners. Data from 2001 estimated the area of hedges to be 117,174 ha for England, Scotland, and Wales (den Herder et al. 2015). Hedgerows and windbreaks cover about 12,400 ha in Belgium (den Herder et al. 2017, based on Etat de l'Environnement en Wallonie 2010). In Hungary, a shelterbelt system of around 16,400 ha could be found in 2001 (Takács - Frank 2008), which is only half of the area occupied

\footnotetext{
${ }^{1}$ non-forest plantation: planting trees on areas, on which agriculture is unprofitable, or along streets, irrigation canals, cisterns, watercourses, or in the surroundings of settlements or monuments (Gál et al. 1960).
} 
by these agroforestry systems in the $90 \mathrm{~s}$. According to the estimation, between $40-80 \%$ of the hedgerows have disappeared in Europe since the end of 1960s (Herzog 2000). The policy in itself was not the only cause; the use of land solely for production was also a factor (Baundry et al. 2000).

Though many traditional agroforestry systems have disappeared with the intensification of agriculture since the 1960 s, a revived interest in integrating trees with agricultural production systems has occurred. "This interest comes from farmers who can see benefits in terms of increased and more diversified production" (den Herder et al. 2015).

The authors of this article would like to draw attention to shelterbelts as effective instruments for agroforestry and for economically and environmentally sustainable agriculture. The study provides a summary of how shelterbelts can help the adaptation to coming global and local challenges through ecosystem services, and offers clear guidelines on the reasonable implementation of shelterbelts.

\section{WINDBREAKS}

Shelterbelts decrease harmful effects mainly by reducing wind speed. The reduction of wind speed through shelterbelts of appropriate structure and direction may generate micro and mezzo climate changes that are advantageous for cultivated crops. Furthermore, these plantations can reduce accident risk on motorways by eliminating snowdrifts caused by crosswinds along roads, as well as limit the spread of pollution, dust, and erosion on bare surfaces. They can also reduce the spread of foul smells. The establishment of a shelterbelt is a relatively cheap solution for protecting agricultural land. The efficiency of reducing wind speed is about $10-15 \%$ on the windward side, and can reach $60 \%$ on the leeward side (Boskovic et al 2010).

The effectiveness of shelterbelts as wind speed reducers can be best described by the openness factor, which is the ratio of wind speeds measured on the protected side behind the belt and those measured in open areas. The openness factor depends on the "porousness" of the shelterbelt's structure measured in its leafy condition. The most effective are the so-called fretwork or porous-structured shelterbelts. In these belts, the gaps that let the moving air through add up to 10 to $30 \%$ to the lateral surface, creating an openness factor of between 0.35 and 0.70 . This means the wind speed on the protected side of the shelterbelt will generally be reduced by $50 \%$. Behind closed plantations (without gaps or at less than $10 \%$ of the lateral surface), turbulence, heat pockets, and frost corners may develop. Open belts (with a gap ratio of more than $30 \%$ ) are ineffective at reducing winds and may even increase wind speed through the socalled echelon-effect (Dömsödi 2010, Gál 1972).

Regarding the widths of shelterbelts, these can be categorized into three main groups. Narrow belts are 6 to 11 meters wide and contain 3 to 7 rows. Medium belts are 12 to 20 meters wide containing 8 to 13 rows, while wide belts with widths of 20 to 30 meters and 14 to 20 rows belong to the category of protecting forests (Gál 1972).

The results of Gál (1961), which assessed the wind-reducing effects of different shelterbelt structures in relation to their height, are summarized in the chart below (the extension of protective effects is given by a multiplier to the height of the trees).

At lower wind speeds, the effectiveness of dense shelterbelts decreases, whereas that of porous ones increases.

Based on research results and economic aspects that were also taken into consideration, the deployment of mainly narrow - 12 to 15 meter wide and 7 to 9 row - porous belts is recommended (Gál 1961).

Recent researches have introduced the concept of total area density (Ad), which is obtained by dividing projected area of leaf, branch, and stem per unit ground area, by the average crown 
length, because most of the total area of vegetation is in the crown mainly. Ad multiplied with the width of the shelterbelt $(\mathrm{Ad} \times \mathrm{W})$ is considered to be a measure of the total surface area per unit length of the shelterbelt obstacle. Torita-Satou (2007) found a significant positive correlation between the sheltered area and $\mathrm{W} \times \mathrm{Ad}$.

Table 1. Efficiency of different shelterbelt structures, $h=$ tree height (based on Gál 1961)

\begin{tabular}{llcc}
\hline \multirow{2}{*}{ Effect } & \multicolumn{3}{c}{$\begin{array}{c}\text { Distance } \\
\text { porous }\end{array}$} \\
\hline \multirow{2}{*}{ Windbreak } & front side & closed & open \\
\hline Highest protection & $5-22 \mathrm{~h}$ & $3-17 \mathrm{~h}$ & $5-10 \mathrm{~h}$ \\
Practically important (min 50\%) wind decrease & $15-49 \mathrm{~h}$ & $15-51 \mathrm{~h}$ & $11-20 \mathrm{~h}$ \\
\hline \multirow{2}{*}{ Pratected side } & $1-5 \mathrm{~h}$ & $1-5 \mathrm{~h}$ & $1-10 \mathrm{~h}$ \\
\hline
\end{tabular}

Curiously, Hungarian experiments showed that snow stopping properties of shelterbelts are not influenced by porousness, but rather by tree height, the geographic structure of the belt, and the surrounding surfaces (Takács 2008). The more complex the obstacle we set up perpendicularly to the wind direction is, the better the expected result should be. A complex 4row plantation alongside the road at a minimum distance of 20 meters, where the line of trees is combined with an edge of shrubs (e.g. articulated in two parts), can be more effective than a conventional 8 to 10 row protective belt. The reason may be that the articulated structure of the 4 row belt and the turbulence created by it can change the direction of the wind vectors and the energy of the particles conveyed by the wind. Thus, the particles settle along the wind-exposed side of the belt in a strip about 20 meters wide in the uncovered area between the belt and the line of trees (shrub) as well as on the embankment between the road and the line of trees.

As described above, in addition to appropriate orientation, the most important factor is to shape the structure so that it is suitable for the purpose of protection. Experience shows that it is unnecessary to plant 15 to 20 row-wide shelterbelts since the first couple of rows of trees can break the strength of winds insofar as it does not endanger the protected area or project.

Model experiments show that the length, height, width, and cross-sectional shape have an effect on the aerodynamic features of the shelterbelt, as well as on the internal structural components, such as the amount and arrangement of its vegetative surface area and volume, as well as the geometric shape of individual vegetative elements (Brandle et al. 2004, Zhou et al. 2004).

\section{MITIGATION, CLIMATE ADAPTATION AND PRODUCTIVITY}

Transpiration and assimilation are much higher in forests than in other forms of vegetation due to the high leaf-surface index, which has a cooling effect on the environment. Thus, the carbon sequestration of the forested areas coupled with agricultural systems may dampen global warming, while enhancing productivity (Amichev et al. 2016, Mátyás (ed. ) 2005).

The effects of shelterbelts that influence the micro-climate (e.g. windbreak, increasing the relative moisture of air, decreasing evaporation, promoting the formation of dew and homogeneous blankets of snow), manifest themselves in increasing agricultural productivity.

Decreased air movements help reduce plant and soil evaporation. This leads to an improved water balance and hydration and, thereby, lower energy requirements to compensate dehydration. Stomas do not close in lighter winds, enabling undisturbed ventilation. Reduced air movement reduces the chilling of the environment; thus, soil and air temperatures increase, which is favourable for germination, the function of plant cells, and soil microbes, too (Szarvas 
2010). The physical damage (twisting by the wind or sandblasting by eroding particles is smaller in the protection of a shelterbelt (Boskovic et al 2010).

Summarizing the results of several researchers (Kölüs 1979, Takács 2008, Abdalla Fangama 2015, Zheng et al. 2016), we can conclude that a 10-12m wide, articulated and at least $20 \mathrm{~m}$ high, but young shelterbelt, supplemented with a shrub zone to break wind and snow, can have a positive effect on crop yield up to a distance of $300 \mathrm{~m}$ for a wide range of crops: groundnuts, cotton, vegetables, cereals, maize.

A statistically evaluated yield analysis was carried out in the 1960s for the seven most important crops (winter wheat, winter and spring barley, alfalfa, maize, carrot, pasture grass) in 18 selected areas in Hungary (Gál 1963). The conclusion was that the production-increasing effect is demonstrable on both sides of the shelterbelt, regardless of their compass orientation. The best result is achieved if shelterbelts are situated perpendicularly to the typical direction of wind. In Hungary, shelterbelts positioned in an east-west direction are the most effective since protection against wild northerly winds and dry southerly winds is extremely important. The danger of drought occurs mainly with winds with a temperature higher than $25^{\circ} \mathrm{C} / 77^{\circ} \mathrm{F}$, and relative moisture lower than $35 \%$.

Concerning the wind-breaking and snow-catching properties of shelterbelts, the width of the protected zone for increased yield is influenced mostly by the height and structure of the shelterbelt; the width has no significant influence.

The width of the effective zone can be 6 to15 times bigger than the height of trees on the northern and southern side of the shelterbelt, while on the eastern and western side, this is limited to 8-10 times. The biggest rise in crop yield has been experienced in a strip 3-10 times wider than the height of the trees.

The favourable effects on climate and yield are more apparent in shelterbelt sites situated in locations that experience weather extremes and drought; the more extreme the conditions, the more apparent the favourable effects become.

Table 2 shows the extra yield on shelterbelt-protected areas, compared to samples taken from unprotected control plots.

Table 2. Extra yield in shelterbelt-protected plots (Based on Gál 1963)

\begin{tabular}{lc}
\hline Plant species & Extra yield $(\%)$ \\
\hline winter wheat & $9.8-26.8$ \\
winter barley & 1.7 \\
spring barley & $6.1-33.5$ \\
alfalfa & $20.3-22$ \\
maize & $2.9-28.7$ \\
carrot & 6.2 \\
pasture grass & 15.3 \\
\hline
\end{tabular}

In comparison, Nuberg (1998) found similar values of the weighted mean yield increase except for alfalfa, which reached $99 \%$ in Australia.

However, as stated in both research studies, somewhat weaker crop yield has been found in areas close to the shelterbelts -a distance ranging from 5-60 m-than in the middle of the plot. In Hungary on the southern edge of the shelterbelt, this negative effect is less significant.

The effect of shelterbelts on crop yield depends on the sensitivity of the crop against wind (Gál 1963).

Nevertheless, shelterbelts increase the overall safety of yield due to the protection they offer against drought and wind damage. 


\section{SOIL PROTECTION}

In agricultural plant producing systems, irrigation alone cannot prevent drought or solve water supply needs; this is particularly true on sites stricken by extreme weather. Irrigation influences soil water balance only. Combating atmospheric drought requires the reduction of dry winds. In the absence of this, the wind continuously replaces the moist air layers that result from evaporation and transpiration. As a result, the need for irrigation increases, and the requirement of secondary salinization in soil occurs. The favourable micro-meteorological effects of shelterbelts result not only in improved productivity of non-irrigated agricultural sites, but also play an important role in increasing irrigation efficiency and soil protection. Beyond that, based on an examination of microflora and microfauna in soil profiles, 8-10-year-old shelterbelts also have a favourable effect on deeper soil layers. Beside soil ventilation, life in the soil is also positively influenced by plantations of mixed stands. Deeper soil layers also have the opportunity to unfold nutrients, which is beneficial for tree growth (Gál et al. 1960, Carnovale et al. 2019). Regarding carbon sequestration, several research studies (Saha et al. 2009, Nair et al. 2010, Lorenz - Lal 2014) reveal that tree plantations on agricultural land can significantly increase soil organic carbon (SOC) content. Long term managed plantations such as shelterbelts can store SOC in the upper soil level similar to adjacent seminatural forests (Lorenz - Lal 2014). Tree species richness increases the amount of stored SOC.

Establishing shelterbelts can provide solutions for damaged areas such as industrial sites, landfills, and sludge reservoirs that cannot be afforested due to their toxicity. In such cases, the area surrounding the contaminated site should be afforested in the interests of environmental protection. Over a longer time period, conditions at these contaminated sites can improve through the benefits shelterbelts provide (windbreak, flue-dust, lixiviation of toxic material), which first enables the settling of natural grass and, later, the growth bushes and trees (Dömsödi 2010).

Shelterbelts also can be a solution for gully erosion, as mentioned in Deng et al. (2015). They recommend an optimal planting density of farmland shelterbelts for the prevention of gully erosion at $1100-1300 \mathrm{~m} / \mathrm{km}^{2}$.

Examining the annual water budget on soils, well-shelterbelts can lead to a favorable process in protected areas: atmospheric precipitation rises, physical evaporation from the soil surface decreases, and the accumulation of considerable water reserves in the soils occurs (Lazarev 2006).

\section{NOISE AND AIR PROTECTION}

Due to their effectiveness and limited space requirements, technological solutions are the most commonly used methods for noise reduction near motorways. Nevertheless, building noise barriers can be disproportionately expensive in cases involving longer road sections or a diffuse noise source with a large extension. In addition to their windbreak function, shelterbelts can also serve as effective noise reducers when the distance of the sound traversing the plantation (so the width of the belt) is a minimum $30-50 \mathrm{~m}$. In this case, noise is reduced up to $3-4 \mathrm{~m}$ height from the surface, but the noise reduction is not more than 10-15 $\mathrm{dB}$ (Islam et al. 2012). However, the literature also refers to the so-called screen-noise created by the whispering leaves of trees, which can have a soothing, relaxing effect.

Plant usage, mainly with sufficiently wide tree or bush rows, has many additional favourable aspects that artificial technical solutions do not provide. For example, in contrast to walls, plants absorb the sound of vehicles rather than reverberate and increase the noise. In 
addition, they also provide all the added benefits green spaces provide, ranging from carbon sequestration to making a microclimate more pleasant (Palotás 1985, Barótfi 2000).

The many problems associated with air pollution validate the air-purifying function of shelterbelts. Tree stands increase the roughness of the surface and cause vortexes in streaming air. The leaves catch not only the precipitation, but also filter out dust, heavy metal, sulphurdioxide, freon, etc. As well as improving the $\mathrm{CO}_{2}$ balance of our atmosphere, forests stands have a significant filter effect against trace gases and aerosols; however, this environmental influence can be fatal for tree stands in extremely polluted areas. Under the effect of vortexes, the transported particles deposit on the surface of leaves, herbaceous plants, and soil (Heath et al. 1999, Islam et al. 2012). The scale of turbulence depends principally on scragginess of crown storey, while adhesion of aerosol particles is influenced by leaf area index (LAI), leaf surface features, and crown structure (Mátyás (ed) 2005). Prominently high deposition values were measured in spruce (Picea) stands, with high surface roughness (Takács 2008).

According to the measurements of Kölüs (1979), the 15-25 ppm CO concentration near the motorway is not demonstrable at the opposite side of the shelterbelt, while $11 \mathrm{ppm}$ concentration in areas without shelterbelts decreases only to $1.2 \mathrm{ppm}$ at a distance of $50 \mathrm{~m}$ from the motorway. A consistent tree plantation at a width of $10-12 \mathrm{~m}$ can catch the deposition of smut as well as gaseous, small-sized particles that may be harmful to respiratory organs. An increasing number of researchers agree (Fórián - Hagymássy 2009, Chen et al. 2015, Amadi et al. 2016, Amadi et al. 2017) that wayside hedgerows or tree plantations can play a significant role in suspending air pollution and salty sprinkle, the contaminated rainwater sprayed by vehicles. Another point of view is that tree stands act as complex "filters" and play an important role in the natural accumulation of pollutants. The typical air drifts connected to afforestation work very much like a conveyor belt as they transport the air moisture, carbon-dioxide, and other gaseous components of metabolism (Willis et al. 2017). The relatively lower temperature in the forest processes an intensive air transport between the atmosphere of the forest and the layer above, which dissolves pollutants into the stand. Forest stands also have their own air circulation, and this helps the pollution engaging effect of the forest.

\section{ECOLOGY}

The wildlife of many areas is affected by human establishment and activity. Human activity and construction alters natural areas, disrupting the contacts between certain wildlife populations, migration opportunities for some individual wildlife species and, finally, affecting the sum of natural living conditions for wildlife. Coherent non-forest tree stands, for example shelterbelts, which can serve as ecological corridors, are suitable for limiting the impacts human activities can have on a landscape (Barna 2004). These ecological corridors, together with protected areas and other semi-natural sites, can create a network of biotope systems, and as "green corridors" can ensure the variegation of sites, life circumstances, communication, and the spread of interconnected plant and animal species. In addition, shelterbelts are ecological systems that can contain significant wildlife; several species within these are natural predators of pests, which can have a beneficial impact on agriculture through pest reduction (Szarvas 2010, Todd et al. 2018, Gontijo 2019). Furthermore, by reducing wind speed, shelterbelts can significantly prevent the spread of some wind-carried pests and aphid-transmitted viruses (Mize et al. 2008).

Though farmers generally consider ecological issues to be of lesser importance than economic factors, they do experience and appreciate the strong correspondence between ecology and crop productivity and sustainability. The influence that the presence of pollinators has on different production systems is a good example of the relationship between ecological and economic factors. 
For example, bees not only directly create food by converting nectar to honey, but more importantly support agriculture through their pollination activity. According to URL1, it is commonly understood that bees are responsible for at least one-third of all global food supplies and billions of dollars of agricultural production. Bee-dependent crops include the majority of tree fruits and berries, several vegetables, and some important forage species such as alfalfa, clovers, and legumes. Having a diverse population of pollinators is even better as this can ensure crops receive some pollination and fruiting even if honeybee populations fail.

Bee keeping is promoted by CAP Pillar II in the European Union, which is the world's second largest honey producer. (Santiago-Freijanes et al. 2016). By providing pollens and nectars for bees, shelterbelts can play a significant role in domestic honey production as well (Donkersley 2019). The wind speed reducing effect of shelterbelts causes a higher amount of pollinating insects on the protected field compared to the open areas. Honey bee (Apis mellifera) flight is inhibited at wind speeds of $6.7-8.9 \mathrm{~m} / \mathrm{s}$ (Mize et al. 2008). By providing pollen and nesting resources for honey and wild bees, shelterbelts positively affect the diversity of the pollinator fauna (Hass et al. 2018). The intensity of the management - both for shelterbelts and adjacent crops - also affects bee diversity (Wu et al. 2019) and total gamma diversity (Duflot et al. 2015).

The changes in agricultural practices and the movement away from diverse landscapes in the past 50 years, has caused a significant decline in pollinator species (Odanaka-Rehan 2019). Multi-canopy layouts with permanent herbaceous soil cover provide year-round benefits to bees and agricultural systems as a whole by lengthening the available term of pollen starting early in the year with willow (Salix sp.) and hazel (Corylus sp.) and then ending with chestnut (Castanea sp.) and English ivy (Hedera helix). Other species are a source of nectar, including maple (Acer sp.), mountain ash (Sorbus sp.), blackthorn (Prunus spinosa), quince (Cydonia oblonga), and elderberry (Sambucus sp.), or honeydew, e.g. poplar (Populus sp.), beech (Fagus $s p$.) or propolis, as oak (Quercus sp.) and certain conifers. These effects can nearly double honey harvest volumes (Clément et al. 2016). Though honey bees are a focus of research because of their dominance in pollinator communities, wild bees and other pollinators can actually be more effective pollinators due to their higher frequency of contact with the flowers (Földesi et al. 2016).

Hundreds of useful wild bee species and subspecies are unique pollinators of many seed crops, including rapeseed for oil, legumes as secondary crops, cultivated fruit plants etc. Open areas may be left inside or on warm margins of larger patches in net nodes when designing shelterbelts to make feeding or nesting areas for game and thermophilous wild bees, spiders, and other insects (Zajączkowski 2016, Morrison et al. 2017).

Semi-natural habitats like shelterbelts also promote the appearance of generally forest-related spider (Araneae) and beetle (Staphylinidae) species that do not occur or are only occasionally found in intensive cultivation areas (Szél - Kádár 2012, Li et al. 2018). Similarly, the species richness and diversity of springtails (Collembola) also highlights the importance of shelterbelts in agricultural environment (Winkler - Traser 2012, 2017). With bird communities, species specific to agricultural fields and specific to forests appear and nest in the shelterbelt system. Also, species that rarely nest in closed forests can often be found in shelterbelts (Jánoska 2011). Similarly, special temporary mammal communities appear in shelterbelt-protected agricultural areas. In addition to the common rodent species and communities of cultivated areas, there is a steady population of generalist rodents of European temperate forests (Németh 2014).

Although amphibians and reptiles are not typical animal communities on farmland, species occurring only in wooded areas also occur in shelterbelts. This underlines the role of such tree plantations as an ecological corridor by facilitating the migration and spread of amphibians (Winkler 2012). 


\section{SOCIO-ECONOMIC ASPECTS}

In recent years, the role of landscapes has significantly changed. Attention is mainly directed to those areas that have been attributed to a single destination such as conventional monoculture agricultural areas. Nowadays, the process of transformation into multifunctional landscapes, where people living in a region rely on a higher variety of resources, can be observed (Schaller et al. 2018). In a multifunctional landscape a typically agricultural area is not only the scene of agricultural production, but also a biological and social living space. Agroforestry systems, including windbreaks and shelterbelts, are necessarily part of these multifunctional landscapes due to their complexity, diversity, and valuable ecosystem services. These services bring benefits to both landowners and society. Landowners benefit from shelterbelts in several ways. While most environmental services such as soil improvement and increased biodiversity effects cannot be estimated due to a lack of information and data, other benefits such as yield increment and energy conservation are measured private benefits of shelterbelts supported by a number of evidences. Society as a whole also benefits from shelterbelts in terms of climate regulation through carbon sequestered in the system, and improvements in water quality and biodiversity (Grala 2004, Kulshreshtha et al. 2018). In addition, the utilization of locally produced biomass brings significant energy savings at the regional or national level and contributes to the achievement of renewable energy targets.

Even though they offer many benefits for farmers, landowners, and society as a whole, shelterbelts have been removed from many livestock farms, croplands and farmsteads worldwide. The reasons for their removal include the following (Grala 2004, Tyndall 2009, Pisanelli et al. 2012, Kulshreshtha et al. 2018, Amichev et al. 2020):

- space needed for buildings, equipment and other infrastructure

- weather damage (flood, storm, fire, etc.)

- damage by human activity (chemical or mechanical effects)

- age of shelterbelt (tree degradation, structure disintegration)

- change of land size and technology (intensification, larger machines, aerial spraying etc.)

- poor market facilities

- labour and time requirements for planting and maintaining trees and shrubs

- the economic consequences of all aspects listed above

- less experience and/or lack of knowledge on behalf of land users and landowners

The use of other agro-ecologically advantageous microclimate and soil improvement land use methods (e.g. no tillage or reduced tillage, mulching, growing cover crops) is another possible factor; the farmers may not perceive the benefits of shelterbelts and thus remove them.

According to some research examining farmer motivations, farmers who decided to maintain or establish shelterbelts did so for a variety of reasons including snowdrift control; dust, sand, noise, spraying, and wind protection; yield increment; livestock protection; firewood production; aesthetic reasons; wildlife habitat; product diversification; and the mitigation of livestock emissions (Dix 1976, Brandle et al. 1984, Vernon et al. 1991, Mertia et al. 2006, Tyndall 2009, Kulshreshtha et al. 2018, Rois-Díaz et al. 2018). Having shelterbelts in arid and environmentally sensitive areas is even more important as shelterbelts play a significant role in optimising yield; furthermore, in certain places and growing seasons, shelterbelts are essential for crop production (Mertia et al. 2006, El Amain - El Madina 2014, Li et al. 2020).

Kulshreshtha et al. (2018), points out that the decisive factors in decisions to remove shelterbelts are the educational attainment long-term planning of landowners.

A number of estimates have been calculated to examine whether it is worth keeping shelterbelts and similar green linear infrastructure elements. The results are wide-ranging; some show little benefit while others estimate a significant impact (Dix 1976, Vernon et al. 1991, 
Mertia et al. 2006, Tyndall 2009, Kulshreshtha et al. 2018, Pisanelli et al. 2019). In a U.S. survey Brandle et al. (1992) concluded that windbreaks are an economically attractive investment over a wide range of conditions. Analysis by Grala (2004) reveals that additional crop yields necessary to break even vary significantly across windbreak scenarios, lifespans and lengths of the protected zone. According to Tyndall (2009), $75 \%$ of Iowa hog producers who believe shelterbelts help to physically and social-psychologically mitigate odours would be willing to pay to plant and maintain shelterbelts. Livestock farmers likely see more direct benefits of shelterbelts than crop producers do, primarily from the social-psychological aspects stemming from public relations related to matters of odour control.

The economic and social value of natural assets can be measured by the sum of all the benefits provided by their ecosystem functions. However, when examining economic aspects, it is very important to emphasize that the large number of factors makes each system special; hence, judging the benefits of maintaining shelterbelts requires a unique calculation tailored to local circumstances. No universal method has been developed to calculate the value of positive externalities due to positive environmental effects, which may be significant. Therefore, the benefits shelterbelts extend to society are not considered by most producers in their management decisions as they offer no compensation for the producers themselves. In contrast, Rempel et al. (2017) found that producer costs were easily identifiable and that these strongly influenced management decisions. Shelterbelt timeframes also complicate the issue. The economic benefits of shelterbelts are only realized after 10-15 years, which is beyond the annual timeframe by which agricultural producers typically operate. This contributes to increased uncertainty that further discourages agricultural producers (Grala, 2004). Moreover, in many cases, available subsidies provide little motivation for farmers to install or maintain shelterbelts.

The positive perception of farmers is a very important step in the adoption of agroforestry practices (Mertia et al. 2006, Pisanelli et al. 2012, Kulshreshtha et al. 2018). Results of a survey undertaken to determine farmers' perceptions of silvoarable agroforestry across Europe in 2003 and 2004 suggest silvoarable agroforestry would become a more common feature of the European landscape if it were provided with appropriate promotion and support (RigueiroRodríguez et al. 2009). CAP should support this type of farming by mutually reinforcing measures rather than through exclusive measures, which should also be thoroughly explained and encouraged by experts. Due to the lack of awareness and practical knowledge, Pisanelli et al. (2012) and Rois-Díaz et al. (2018) highlights the importance of promotion at the institutional level through training and extension activities with the aim of raising awareness of available support in addition to practical knowledge of farming and alternatives. In order to promote agroforestry, it is also essential to draw consumer attention to the quality of agroforestry products and the ecosystem services provided by agroforestry systems.

\section{POSSIBLE NEGATIVE EFFECTS OF SHELTERBELTS ON ADJACENT CROP}

Though shelterbelts have many advantages, they do have some disadvantages as well. The shade of the trees, the competition, and the spread of invasive plants have a negative effect on crop yield. The most common mentioned handicap of the plantations in agricultural land is the competition between woody vegetation and the adjacent crops, especially under conditions of limited moisture (Brandle, et al. 2004, Jørgensen 2009). Generally, the competitive zone is 1-2 $\mathrm{h}$ ( $\mathrm{h}$ is the height of the trees), where the yield loss can reach 49\% (Nuberg 1998). Although competition is mainly for soil water content (Kowalchuk et al. 1995), tree shade reduces opportunities for photosynthesis, and the roots increase demand on soil nutrients. The allelopathic effect of litter also causes yield loss (Nuberg 1998). Theoretically, without wind, the effects of shelterbelts would be negative; on the other hand, the trees reduce evaporation 
and maintain moisture by decreasing wind, which is a positive effect for crop yield (Vandermeer 1989).

Shelterbelt competition can be decreased by root-pruning. The effectiveness of this depends on the rooting characteristics of the trees/shrubs. A root cut in the top $60 \mathrm{~cm}$ of the soil at $0.5 \mathrm{~h}$ distance from the trees eliminates the crop yield reduction for three years (Kort 1988, Kowachuk et al. 1995).

The sensitivity of different crops for competition is various. While wheat and oats show a larger loss in the shade of shelterbelts, the reduction in alfalfa and other perennial hay crop yields is smaller. Corn showed no apparent yield loss due to competition (Brandle et al. (ed) 1988).

Although shelterbelts can provide habitat for wildlife, they may also promote the spread of undesirable, for example invasive plant and animal species. The role of valuable or desirable species also can be disadvantageous, particularly when they feed on crops rather than on pests and weeds (Mize et al. 2008).

In addition to the disadvantages of the shelterbelts, the lack of theoretical knowledge and practical experience about managing tree plantations is a great limiting factor for farmers (Stancheva et al. 2006). Based on crop yield measurements, the installation of a shelterbelt will pay off in the long run (Easterling et al. 1997). The protection effect appears after the trees are 6 years old and increases yearly, reaching the full efficiency at the age of 20 (Garrett - Buck 1997).

\section{GUIDELINES FOR THE ESTABLISHMENT AND MAINTENANCE OF SHELTERBELTS}

The positive effects of shelterbelts will only prevail with well-prepared planning, appropriate installation, and targeted usage (Yang et al. 2018). Therefore, some guidelines for the structure and choice of tree species should be taken into consideration during installation. Takács (2008) determines the ideal shelterbelt structure as the following (Figure 1):

- an additional line of trees or shrubs should be settled on the windward side, 12-20 meters from the edge of the shelterbelt,

- the windward side of the shelterbelt should be permeable and higher than the accompanying shrub or tree line

- an open area between the shelterbelt and shrub line should be left

- trunk density should be high on windward side and thinning dense towards the leeward side

- tree heights in the interior lines should be diverse (two-storey stands)

- the shape of the protected (leeward) side should be slope or stepped

- leeward edge does not extend beyond the crown projection of the outer tree-line 


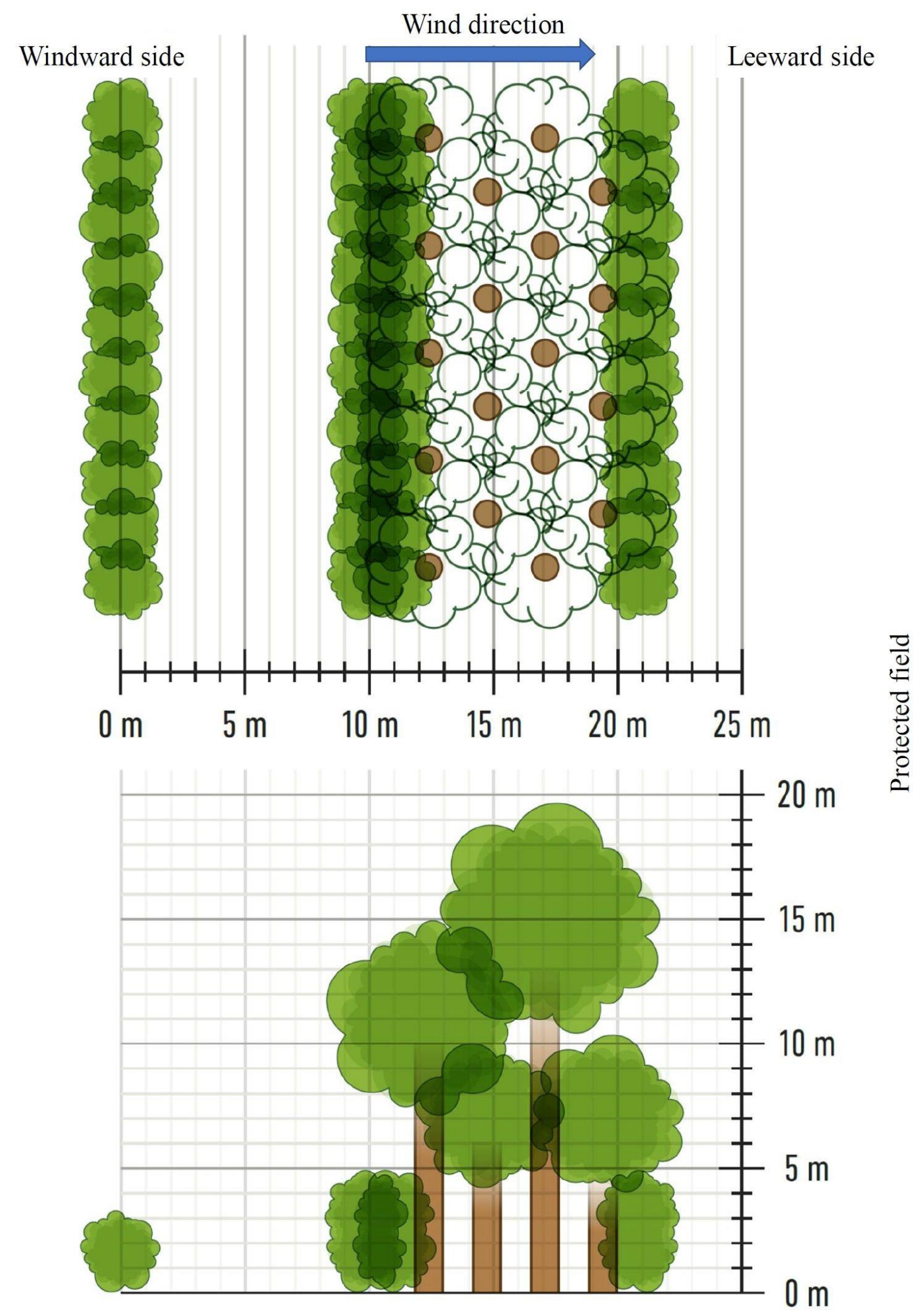

Figure 1. Ideal shelterbelt structure

Starting from the protected site, a two-meter-high bushy strip is settled at 10 meters from the belt. The edge of the belt is 3-4 meters wide and 5-6 meters high; 2 lines, 1 meter line spacing, extending into the trunk space. Distances between the rows of trees are 1-1.5 meters long, the trees are offset from each other. The height of the first line of trees is 15-16 meters, 
line 2 is $10-12$ meters, line 3 is $18-20$ meters and line 4 is $10-12$ meters high. The edge on the protected side has a more simple structure and reaches into the stand by $2-3$ meters. In this way, the bandwidth can be maximized to 10-12 meters.

When using forest belt to protect against snow drifts the distance from the traffic lane border should be at least 7 meters ( 10 meters without borders), but should not exceed 20 meters. For this purpose, the use of two lines of shrubs and 2-3 tree lines on the exposed side while one shrub-line on the protected side of the belt is sufficient.

\section{Road}

Besides forming a harmonic relationship between the artificial lines of traffic and landscape, the aim of roadside afforestation is to improve traffic safety. Afforestation is used with the goal of drawing attention to the road, accident prevention (forewarning of dangerous points, end of road, slip road), and as an "optical stopper" effect. Other functions connected with this are optical lead, shadowing the road, and protection against snow and wind. Furthermore, afforestation plays a role in improving aesthetic and landscape values (fine view) (Takács 2008).

\section{Species}

Tree and shrub species that primarily develop the appropriate belt structure providing suitable protective effects are recommended for instillation in shelterbelts. In the site conditions of the protected area, these species are able to grow quickly, form plant communities, and contribute to the preservation of soil fertility. They are resistant to disease and weeds, and less sensitive to chemicals used in agriculture. In addition to giving wood and fruits, they also serve as beepastures. Wind resistance is also an important factor of selection (Table 3).

Table 3. Classification of tree species according to their wind resistance (based on Barna 2004)

\begin{tabular}{ll}
\hline Wind resistant species & $\begin{array}{l}\text { poplars (Polulus sp.), pedunculate oak (Quercus robur), } \\
\text { lime (Tilia cordata), elm (Ulmus minor), alder (Alnus glutinosa), } \\
\text { black locust (Robinia pseudoacacia) }\end{array}$ \\
\hline $\begin{array}{l}\text { Moderately } \\
\text { wind resistant species }\end{array}$ & $\begin{array}{l}\text { Hungarian ash (Fraxinus angustifolia), larch (Larix sp.), } \\
\text { beech (Fagus sp.), maple (Acer platanoides), } \\
\text { bigleaf lime (Tilia platyphyllos) }\end{array}$ \\
$\begin{array}{l}\text { Physiologically } \\
\text { wind-sensitive species }\end{array}$ & $\begin{array}{l}\text { hornbeam (Carpinus betulus), birch (Betula pendula), } \\
\text { pine (Pinus sylvestris), red oak (Quercus rubra), } \\
\text { aspen (Populus tremula), spruce (Picea abies), } \\
\text { white pine (Pinus strobus), and common fir (Abies alba) }\end{array}$ \\
\hline
\end{tabular}

In order to design the optimal structure of the upper canopy, main tree species should be selected in line with the specific site conditions. By using the proper species, the maintenance of the shelterbelt will be sustainable for a long time. It is also important that a resistant tree community with spread crown can be developed. The upper level is complemented by filling tree species of the second level. These may already be shade-tolerant tree species, but utilizing the given habitat conditions in the best possible way is necessary to help the growth of trees in the upper level. The shrub layer is also a structuring element whose main task is to protect the soil of the shelterbelt beyond forming its edge. Evergreen pines, juniper, thuja, and thickbranched shrubs can be considered for the purpose of protection against winter and spring winds. Thus, forest belts will not become open in winter; their snow-retaining ability will grow and they may serve as winter shelter for wild animals. 
The design of shelterbelts requires simplicity. Excellent combinations can be developed by the use of one or two main tree species, one to two complementary tree species, and one-tothree shrub species. By contrast, the aim in the proximity of protected areas is to develop a diverse combination of species providing stability. Tree and shrub species having advanced root systems that can compete with agricultural crops e.g. Salix alba, Tilia cordata, Fraxinus pennsylvanica (Gencsi - Vancsura 1992) are not recommended for installation. In addition, those species that have strong root-shooting abilities, are wind or frost sensitive, and are less resistant to disease or potential intermediate hosts of insects damaging crops, should also be avoided (Table 4) (Gál - Káldy, 1977).

Table 4. Attributes of shelterbelt types (Gál-Káldy, 1977)

\begin{tabular}{|c|c|c|c|c|}
\hline Type & $\begin{array}{l}\text { Complementary } \\
\text { tree species }\end{array}$ & $\begin{array}{l}\text { No. of } \\
\text { rows }\end{array}$ & $\begin{array}{l}\text { Width } \\
(\mathrm{m})\end{array}$ & Soil condition \\
\hline $\begin{array}{l}\text { giant poplar (Populus } x \\
\text { canadensis "Robusta") }\end{array}$ & $\begin{array}{l}\text { maple } \\
\text { (Acer platanoides) }\end{array}$ & 5 & 9 & $\begin{array}{l}\text { loamy agricultural soil, } \\
\text { alluvial soil, peat soil, } \\
\text { sandy soil }\end{array}$ \\
\hline $\begin{array}{l}\text { Italian poplar (Populus } \\
\text { italica) }\end{array}$ & $\begin{array}{l}\text { bigleaf lime } \\
\text { (Tilia platyphyllos) }\end{array}$ & 4 & 7,5 & $\begin{array}{l}\text { farmland with good } \\
\text { nutrition supply, } \\
\text { peat soil of better quality }\end{array}$ \\
\hline $\begin{array}{l}\text { giant poplar (Populus } x \\
\text { canadensis "Robusta") }+ \\
\text { pedunculate oak } \\
\text { (Quercus robur) }\end{array}$ & $\begin{array}{l}\text { large leaved lime } \\
\text { (Tilia platyphyllos) }\end{array}$ & 8 & 12,5 & $\begin{array}{l}\text { nutrient-rich alluvial soils, } \\
\text { heavy clay soil, } \\
\text { humus sand, } \\
\text { improved saline soil }\end{array}$ \\
\hline $\begin{array}{l}\text { black locust (Robinia } \\
\text { pseudoacacia) }\end{array}$ & $\begin{array}{l}\text { oleaster } \\
\text { (Elaeagnus } \\
\text { angustifolia) }\end{array}$ & 7 & 11 & $\begin{array}{l}\text { sandy soils (not applicable } \\
\text { in heavy soils) }\end{array}$ \\
\hline $\begin{array}{l}\text { pine (Pinus sylvestris), } \\
\text { red oak (Quercus rubra) }\end{array}$ & - & 5 & 8 & $\begin{array}{l}\text { not too heavy clay, } \\
\text { loamy- or nutrient-dense } \\
\text { sandy soil }\end{array}$ \\
\hline $\begin{array}{l}\text { lime (Tilia cordata) }+ \\
\text { sessile oak (Quercus } \\
\text { petraea) }\end{array}$ & $\begin{array}{l}\text { maple (Acer sp.), } \\
\text { elm (Ulmus sp.), } \\
\text { alder (Alnus glutinosa) }\end{array}$ & 10 & 15,5 & $\begin{array}{l}\text { dry, slightly acidic soil } \\
\text { with thin topsoil }\end{array}$ \\
\hline
\end{tabular}

Beyond planning and creating the structure, proper maintenance is critical to keeping the integrity of the shelterbelt spatially and through time. This is more difficult in systems where all the individual trees and shrub components have been planted at the same time. However, the management techniques of shelterbelts can be similar to general forest management, the purpose is different. In case of shelterbelts, the aim of the management is to maintain their effectiveness. The activities begin soon after planting with weed control till the canopy layer closure (Zhu 2008). Later, the goal of management is to maintain the diverse structure and porosity of the shelterbelt (Takács 2008).

Consequently, in the absence of regeneration, effectiveness will decrease due to natural mortality. It is therefore important to use a diversity of species in protective plantations and inspect them regularly in order to identify and restore vulnerable parts of shelterbelts (Xie et al. 2018, URL2). A properly planned and planted shelterbelt comprises a very small portion of the agricultural land, and their advantages are many times greater than their negative effects (Mize et al. 2008). 
The current Hungarian support system does not give detailed guidelines for implementing a shelterbelt. The number of trees in an agroforestry system is limited to 200-250 pieces/ha. The width of the shelterbelt is defined from 15 to $20 \mathrm{~m}$, and a $1 \mathrm{~m}$ wide shrub belt must be planted in both sides. In order to reach the maximum efficiency and ecological benefits, the available research results on the appropriate structure and species composition should be taken into account in the future support regulation.

Acknowledgements: The project was supported by EFOP-3.6.2-16-2017-00018 in University of Sopron project.

\section{REFERENCES}

AbDalla, Y.Y. - FAngama, I.M. (2015): Effect of Shelterbelts on Crop Yield in Al-Rahad Agricultural Scheme, Sudan. Int. J. Curr. Microbiol. App. Sci 4(7): 1-4.

AKPOTI, K. - KABO-BAH, A. - ZWART, S. J. (2019): Agricultural land suitability analysis: State-of-theart and outlooks for integration of climate change analysis. Agricultural Systems 173: 172-208. https://doi.org/10.1016/j.agsy.2019.02.013

AMADI, C. C. - FARRELl, R. E. - VAN REES, K. CJ. (2017): Greenhouse gas emissions along a shelterbelt-cropped field transect. Agriculture, Ecosystems and Environment 241: 110-120. https://doi.org/10.1016/j.agee.2016.09.037

AmADI, C. C. - VAN ReES, K. CJ. - FARRELl, R. E. (2016): Soil-atmosphere exchange of carbondioxide, methane and nitrousoxide in shelterbelts compared with adjacent cropped fields. Agriculture, Ecosystems and Environment 223: 123-134.

https://doi.org/10.1016/j.agee.2016.02.026

AMiCHEV, B.Y. - BENTHAM, M.J. - KURZ, W.A. - LAROQUe, C.P. - KUlShRESHTHA, S. - PiWOWAR, J.M. - VAN REES, K. CJ. (2016): Carbon sequestration by white spruce shelterbelts in Saskatchewan, Canada: 3PG and CBM-CFS3 model simulations. Ecological Modelling 325: 3546. https://doi.org/10.1016/j.ecolmodel.2016.01.003

AMICHEV, B.Y. - LAROQUE, C.P. - VAN REES, K.C.J. (2020): Shelterbelt removals in Saskatchewan, Canada: implications for long-term carbon sequestration. Agroforestry Systems (2020) https://doi.org/10.1007/s10457-020-00484-8

BARNA, T. (2004): Miért van szükség erdősávrendszerekre? [Why are shelterbelts necessary?] Növényvédelmi tanácsok. XIII./2: 38-39. (in Hungarian)

BARÓTFI, I. (2000): Környezettechnika. [Environmental Techniques] Mezőgazda Kiadó, Bp. (in Hungarian)

BAUNDRY, J. (2000): Hedgerows: An international perspective on their origin, function and management. Journal of Environmental Management 60 (1): 7-22. https://doi.org/10.1006/jema.2000.0358

Boskovic, J. - ZelJANA, P. - IVANC, A. (2010): Economical and ecological impact of shelterbelts. Economics of Agriculture 57 (2): 51-57.

BRANDlE J.R. - HinTZ D.L. - StURROCK J.W. (1988): Windbreak Technology. Elsevier Science Publishers, Amsterdam, 598 pp.

BRAndLE, J.R. - HodgeS, L. - ZHOU, X.H. (2004): Windbreaks in North American agricultural systems. Agroforestry Systems 61: 65-78. https://doi.org/10.1023/b:agfo.0000028990.31801.62

BRANDLE, J.R. - JoHNSON, B.B. - AKeSON, T. (1992): Field Windbreaks: Are They Economical? Journal of Production Agriculture 5 (3): 393-398. https://doi.org/10.2134/jpa1992.0393

BRANDLE, J.R. - JOHNSON, B.B. - DEARMONT, D.D. (1984): Windbreak economics: The case of winter wheat production in eastern Nebraska. Journal of Soil and Water Conservation 39: 339-343.

Carnovale, D. - Bissett, A. - Thrall, P. H. - BAKer, G. (2019): Plant genus (Acacia and Eucalyptus) alters soil microbial community structure and relative abundance within revegetated shelterbelts. Applied Soil Ecology 133: 1-11.

https://doi.org/10.1016/j.apsoil.2018.09.001

Acta Silv. Lign. Hung. $16(1), 2020$ 
Chen, X. - Pei, T. - Zhou, Z. - Teng, M. - He, L. - LuO, M. -LIU, X. (2015): Efficiency differences of roadside greenbelts with three configurations in removing coarse particles (PM10): A street scale investigation in Wuhan, China. Urban Forestry \& Urban Greening 14: 354-360. https://doi.org/10.1016/j.ufug.2015.02.013

Clément, H. - CANET, A. - ASFAuX, D. - BALAguer, F. (2016): Without trees no bees: agroforestry for a productive and bee-smart agriculture. 3rd European Agroforestry Conference Montpellier, France, 23-25 May 2016 Book of Abstracts.

DANSZKY, I. (ed) (1972): Erdőművelés. [Forest management] Mezőgazdasági Kiadó Budapest. (in Hungarian)

Den Herder, M. - Moreno, G. - Mosquera-Losada, M.R. - PAlma, J.H.N. - Sidiropoulou, A. - Santiago Freijanes, J. - Crous-Duran, J. - Paulo, J. - Tomé, M. - Pantera, A. Papanastasis, V. - Mantzanas, K. - Pachana, P. - BuRgess, P.J. (2015): Current extent and trends of agroforestry in the EU 27. Deliverable Report 1.2 for EU FP7 Research Project: AGFORWARD 613520. (4 December 2015). 99 p. Available online: http://agforward.eu/index.php/en/current-extent-and-trends-of-agroforestry-in-the-eu27.html

DEN Herder, M. - Moreno, G. - MosQUera-LOSAdA, R.M. - PALMA, J.H.N. - Sidiropoulou, A. SANTIAgo FreiJanes, J.J. - Crous-Duran, J. - Paulo, J.A. - TOMÉ, M. - PANTERA, A. PAPANASTASIS, V.P. - MANTZANAS, K. - PACHANA, P. - PAPADOPOUlOS, A. - PliENINGER, T. BURGESS, P.J. (2017): Current extent and stratification of agroforestry in the European Union. Agriculture, Ecosystems \& Environment 241: 121-132. https://doi.org/10.1016/j.agee.2017.03.005

DENG, R. - WANG, W. - FANG, H. - YAO, Z. (2015): Effect of farmland shelterbelts on gully erosion in the black soil region of Northeast China. J. For. Res. 26 (4): 941-948. https://doi.org/10.1007/s11676-015-0110-4

DIX, M.E. (1976): Impact of hardwood borers on Great Plains shelterbelts. In: Forest Service, U.S. Department of Agriculture, Washington D.C.: Research on insect borers of hardwoods. Current status, needs, and application. Proceedings of a Research Coordination Meeting. Forest Insect and desease Research. Dealaware, Ohio, 30-31 March, 1976.

DÖMSÖDI, J. (2010): Tájrendezés és tájvédelem 4. Tájrendezési (tervezési) formák. [Landscape planning and protection] Nyugat-magyarországi Egyetem. (in Hungarian)

DoNKERSLEY, P. (2019): Trees for bees. Agriculture, Ecosystems and Environment 270-271: 79-83. https://doi.org/10.1016/j.agee.2018.10.024

DUFLOT, R. - AVIRON, S. - ERNOULT, A. - FAHRIG, L. - BUREL, F. (2015): Reconsidering the role of 'semi-natural habitat' in agricultural landscape biodiversity: a case study. Ecol Res 30: 75. https://doi.org/10.1007/s11284-014-1211-9

EASTERLING, W.E. - HAYS, C.J. - EASTERLING, M.K. - BRANDLE, J.R. (1997): Modelling the effect of shelterbelts on maize productivity under climate change: An application of the EPIC model. Agriculture, Ecosystems and Environment 61: 163-176 https://doi.org/10.1016/S0167-8809(96)01098-5

Echavarren, J. M. - BAlzeKIENE, A. - Telesiene, A. (2019): Multilevel analysis of climate change risk perception in Europe: Natural hazards, political contexts and mediating individual effects. Safety Science 120: 813-823. https://doi.org/10.1016/j.ssci.2019.08.024

El Amain, K.B. - El MadinA, A.M. (2014): Farmers Perceptions and Attitudes towards the Shelterbelts Establishmentin Farms, Gedarif State, Sudan. SUST Journal of Agricultural and Veterinary Sciences (SJAVS) 15 (2) 26-34.

EUROPEAN COMMISSION (2013): Communication from the Commission to the European Parliament, the Council, the European Economic and Social Committee and the Committee of the Regions. A new EU Forest Strategy: for forests and the forest-based sector. Retrieved on 26 June 2016. from: http://ec.europa.eu/agriculture/forest/strategy/communication en.pdf

EUROPEAN ENVIRONMENTAL AGENCY, EEA (2007): Environmentally compatible bio-energy potential from European forests. Retrieved on 22 August 2012 from:

http://www.efi.int/files/attachments/eea bio energy 10-01-2007 low.pdf

FERRANTI, F. (2014): Energy wood: A challenge for European forests Potentials, environmental implications, policy integration and related conflicts. EFI Technical Report 95. 
FÖldESI, R. - KovÁCs-HOSTYÁNSZKI, A. - KÖRÖSI, Á. - SOMAY, L. - ElEK, Z. - MARKÓ, V. SÁROSPATAKI, M. - BAKOS, R. - VARGA, Á. - NYISZTOR, K. - BÁLDI, A. (2016): Relationships between wild bees, hoverflies and pollination success in apple orchards with different landscape contexts. Agricultural and Forest Entomology, 18: 68-75. https://doi.org/10.1111/afe.12135

FóRIÁN, S. - HAGYMÁSSY, Z. (2009): Zöldfelületek szerepe az urbanizált környezetben. [The role of green areas in urban environment] Debreceni Müszaki Közlemények 2009/1-2 (in Hungarian)

FRANK, N - TAKÁCS, V. (2012): Hó- és szélfogó erdősávok minősítése szélsebesség-csökkentő hatásuk alapján [Qualification of windbreaks and shelterbelts based on their effects on windspeed] Erdészettudományi Közlemények 2 (1): 151-162.

GÁL, J. - KÁLDY, J. (1977): Erdősítés. [Afforestation] Akadémia Kiadó, Budapest. 3-640. (in Hungarian)

GÁl, J. - PÁNTOS, Gy. - PÁntosné, T. D. - SzabÓ, E. - VARGA, L. (1960): Adatok a fásítás termőhelymódosító hatásához az öntözőcsatornák mentén. [Data to the habitat-modifying effect of afforestation by irrigation canals] In: Erdészettudományi Közlemények 1960: 3-43. (in Hungarian)

GÁL, J. (1961): Az erdősávok hatása a szél sebességére. [The effect of shelterbelts on wind speed] In: Erdészettudományi Közlemények 1961: 3-69. (in Hungarian)

GÁL, J. (1963): A mezőgazdasági terméshozamok növekedése az erdősávok védelmében. [The increase of crop yield under the protection of shelterbelts] In: Erdészettudományi Közlemények 1963 (12): 41-83. (in Hungarian)

GÁL, J. (1972): A mezővédő fásítások tervezési és kivitelezési irányelvei. [The planning and implementation of field protection wood plantations] - Erdészeti tájrendezés és környezetvédelem, EFE Erdőmérnöki Kar, Sopron, 47-59. pp. (in Hungarian)

GARRETT, H.E.G. - BUCK, L. 1997: Agroforestry practice and policy in the United States of America. Forest Ecology and Management 1: 5-15. https://doi.org/10.1016/S0378-1127(96)03884-4

GENCSI, L - VANCSURA, R (1992): Dendrológia. [Dendrology] Mezőgazda Kiadó, Bp. (in Hungarian)

GONTIJO, L. M. (2019): Engineering natural enemy shelters to enhance conservation biological control in field crops. Biological Control 130: 155-163. https://doi.org/10.1016/j.biocontrol.2018.10.014

GRALA, R.K. (2004): An evaluation of the benefits and costs of in-field shelterbelts in Midwestern USA. Dissertation. Iowa State University Ames, Iowa.

Hass, A.L. - LiESE, B. - HeOng, K.L. - Settele, J. - TscharntKe, T. - WestPhal, C. (2018): Plantpollinator interactions and bee functional diversity are driven by agroforests in rice-dominated landscapes. Agriculture, Ecosystems and Environment 253: 140-147. https://doi.org/10.1016/j.agee.2017.10.019

HeAth, B.A. - MAughan, J.A. - Morrison, A.A. - EASTwood, I.W. - Drew, I.B. - LofKin, M. (1999): The influence of wooded shelterbelts on the deposition of copper, lead and zinc at Shakerley Mere, Cheshire, England. The Science of the Total Environment 235: 415-417. https://doi.org/10.1016/S0048-9697(99)00250-8

HERCZOG, F. (2000): The importance of perennial trees for the balance of northern European agricultural landscapes. Unasylva 51:42-48

Islam, N. - RAHMAN, K.S. - BAHAR, M. - HABIB, A. - ANDO, K. - HATTORI, N. (2012): Pollution attenuation by roadside greenbelt in and around urban areas. Urban Forestry \& Urban Greening 11:460 - 464. https://doi.org/10.1016/j.ufug.2012.06.004

JÁNOSKA, F. (2011): Fészkelő madárállományok monitoringja erdősávokban. [The monitoring of nesting bird communities in shelterbelts] Ornis Hungarica 19: 125-132. (in Hungarian)

JøRGENSEN, S.E. (Ed.) (2009): Ecosystem ecology. Academic Press.

KARJAlAinen, T. - ASIKAINEN, A. - ILAVSKY, J. - ZAMBONI, R. - HOTARI, K.E. - RÖSER, D. (2004): Estimation of Energy Wood Potential in Europe. Natural Resources Institute Finland, Helsinki

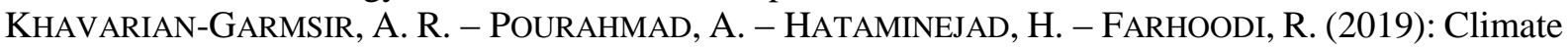
change and environmental degradation and the drivers of migration in the context of shrinking cities: A case study of Khuzestan province, Iran. Sustainable Cities and Society 47: 101480. https://doi.org/10.1016/j.scs.2019.101480

KöLÜS, G. (1979): Nagyforgalmú közutak melletti útvédő erdősávok környezetvédelmi jelentősége. [The environmental impact of shelterbelts by the side of high traffic roads] Erdészeti Lapok 114 (7): 295:302 (in Hungarian) 
KORT, J. (1988): Benefits of windbreaks to field and forage crop. Agriculture, Ecosystems and Environment 22-23: 165-190. https://doi.org/10.1016/0167-8809(88)90017-5

KowalchuK, T. E. - de JONG, E. (1995): Shelterbelts and their effect on crop yield. Can. J. Soil Sci. 75: 543-550

KULSHRESHTHA, S.N. - AHMAD, R. - BELCHER, K. - RUDD, L. (2018): Economic-environmental impacts of shelterbelts in Saskatchewan, Canada. WIT Transactions on Ecology and the Environment, 215: 277-286. https://doi.org/10.2495/EID180251

LAZAREV, M. M. (2006): Transformation of the Annual Water Budget of Soils under Shelterbelts. Eurasian Soil Science, 39 (12): 1318-1322. https://doi.org/10.1134/S1064229306120064

LI, X - LIU, L. - XIE, J. - WANG, Z. - YANG, S. - ZhanG, Z. - QI, S. - LI, Y. (2020): Optimizing the quantity and spatial patterns of farmland shelter forests increases cotton productivity in arid lands. Agriculture, Ecosystems \& Environment, 292: 106832.

https://doi.org/10.1016/j.agee.2020.106832

LI, X. - LIU, Y. - DUAN, M. - YU, Z. - AXMACHER, JC. (2018): Different response patterns of epigaeic spiders and carabid beetles to varyingenvironmental conditions infields and semi-natural habitats of anintensively cultivated agricultural landscape. Agriculture, Ecosystems and Environment 264: 54-62. https://doi.org/10.1016/j.agee.2018.05.005

LORENZ, K. - LAL, R. (2014): Soil organic carbon sequestration in agroforestry systems. Agronomy for Sustainable Development, Springer Verlag/EDP Sciences/INRA, 34 (2): 443-454. https://doi.org/10.1007/s13593-014-0212-y

LuetZENBuRG, G. - BitTNer, M. J. - CAlSAMiglia, A. - RenSChler, C. S. - Estrany, J. - PoepPl, R. (2019): Climate and land use change effects on soil erosion in two small agricultural catchment systems Fugnitz - Austria, Can Revull - Spain, Science of the Total Environment 704: 135389 https://doi.org/10.1016/j.scitotenv.2019.135389

MÁTYÁs, Cs. (ED) (2005): Erdészeti ökológia. [Forestry Ecology] Mezőgazda Kiadó, Bp. (in Hungarian)

MERTIA, R.S. - PRASAD, R. - GAJJA, B.L. - SAMRA, J.S. - NARAIN, P. (2006): Impact of shelterbelts in arid region of Western Rajastan. Central Arid Zone Research Institute, Regional Research Station, Jaisalmer. Evergreen Printers, Jodhpur, 2006.

Mize, C.W. - Brandle, J.R. - Schoeneberger, M.M. - BentruP, G. (2008): Ecological Development and Function of Shelterbelts in Temperate North America. In: Jose S, Gordon M (ed): Toward Agroforestry Design. Advances in Agroforestry 4: 27-54. https://doi.org/10.1007/978-1-4020-6572-9_3

MORRISON, J. - IZQUIERDO, J. - PLAZA, E.H. - GONZÁLEZ-ANDÚJAR, J.L. (2017): The role of field margins in supporting wild bees in Mediterranean cereal agroecosystems: Which biotic and abiotic factors are important? Agriculture, Ecosystems and Environment 247: 216-224. https://doi.org/10.1016/j.agee.2017.06.047

NAIR, P.K.R. - NAIR, D.V. - KUMAR, B.M. - ShOWALTER, J.M. 2010: Carbon Sequestration in Agroforestry Systems. Advances in Agronomy 108: 237-307.

https://doi.org/10.1016/s0065-2113(10)08005-3

NÉGYESI, G. (2018): Mezővédő fásítások tér- és időbeli változásának vizsgálata a Nyírségben - a szélerózió szemszögéből. [The changes in space and time of field protecting wood plantations in Nyírség - from the point of view of wind erosion] Tájökológiai Lapok 16 (2): 113-128. (in Hungarian)

NÉMETH, Cs. (2014): Kisemlős közösségek vizsgálata a Lajta project erdősávrendszerében. [investigation on small mammal communities in the Lajta project forest belt system] Magyar Apróvad Közlemények 12: 275:356 (in Hungarian)

NUBERG, I.K. (1998): Effects of shelter on temperate crops: a review to refine research for Australian conditions. Agroforestry Systems 41: 3-34. https://doi.org/10.1023/A:1006071821948

ODANAKA, K.A. - REHAN, S.M. (2019): Impact indicators: Effects of land use management on functional trait and phylogenetic diversity of wild bees. Agriculture, Ecosystems and Environment 286: 106663. https://doi.org/10.1016/j.agee.2019.106663

PALOTÁs, L. (1985): Mérnöki Kézikönyv III. [Engineering Manual] Müszaki Könyvkiadó Bp. (in Hungarian) 
PisAnelli, A. - Perali, A. - PARIs, P. (2012): Potentialities and uncertainties of novel agroforestry systems in the European C.A.P.: farmers' and professionals' perspectives in Italy. L'Italia Forestale e Montana / Italian Journal of Forest and Mountain Environments 67 (3): 289-297, 2012. https://doi.org/10.4129/ifm.2012.3.07

Pisanelli, A. - Smith, J - Westaway, S. - Ghaley, B.B. - Mølgaard, L.L. - Borek, R., ZAJĄCZKowski, J. - Mignon, S. - GligA, A.E. - Fereres, E. - LóPEZ, M. - Tenreiro, T.R. RÖHRIG, N. - VON OPPENKOWSKI, M. - ROESLER, T. - HASSLER, M. (2019): Technical guidelines for farmers and other stakeholders, factsheets on case studies and preparation of policy briefs. WP5. Dissemination of outputs and communication to stakeholders Report. SUSTAINFARM project. pp. 32-37

REMPEL, J.C. - KULSHRESHTHA, S.N. - AMICHEV, B.Y. - VAN REES, K.C.J (2017): Costs and benefits of shelterbelts: A review of producers' perceptions and mind map analyses for Saskatchewan, Canada. Can. J. Soil Sci. 97: 341-352 https://doi.org/10.1139/cjss-2016-0100

RigueIRo-RodrígueZ, A. - MCADAM, J. - MosQUERA-LOSADA M.R. (Eds.) (2009): Agroforestry in Europe: Current Status and Future Prospects. Advances in Agroforesry 6: 67-86. https://doi.org/10.1007/978-1-4020-8272-6

RoIS-DÍAZ, M. - LOVRIC, N. - LOVRIC, M. - FERREIRo-DomíngueZ, N. - MOSQUERA-LOSADA, M. R. - M. Den Herder, M. - Graves, A. - Palma, J. H. N. - Paulo, J. A. - Pisanelli, A. - Smith, J. - Moreno, G. - García, S. - VArga, A. - PAntera, A. - Mirck, J. - Burgess, P. (2018): Farmers' reasoning behind the uptake of agroforestry practices: evidence from multiple casestudies across Europe. Agroforest Syst 92: 811-828. https://doi.org/10.1007/s10457-017-0139-9

SAHA, S.K. - NAIR, P.K.R. - NAIR, V.D. - KUMAR, B.M. (2009): Soil carbon stock in relation to plant diversity of homegardens in Kerala, India. Agrofor Syst 76: 53-65. https://doi.org/10.1007/s10457-009-9228-8

SANTIAGO-FreiJANES, J. J. - Mosquera-LosadA M. R. -PisAnelli, A. -LAMERSDORF, N. -

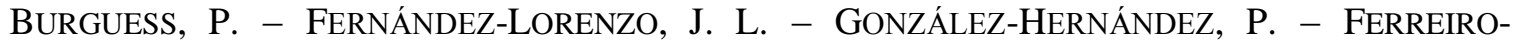
DomínGUEZ, N. - RigueIRO-RodRíGUEZ, A. (2016): Agroforestry in the rural development CAP: Pillar II. 3rd European Agroforestry Conference Montpellier, France, 23-25 May 2016 Book of Abstracts.

Schaller, L. - TARgetti, S. - VillanueA, A.J. -ZASAdA, I. - KANTElHARdT, J. -ARRiaZA, M. BAL, T. -FedrigotTi, V.B. -GiraYi, F.H. - HÄFNer, K. - MAJEWSKi, E. - MALAKRAwlikowska, A. - Nikolov, D. -PAOLI, J.C. -PiorRe, A. - RodrígueZ-EnTRENA M. Ungaro, F. - Verburg, P.H. - VAN ZANTEN, B. - ViAgGi, D. (2018): Agricultural landscapes, ecosystem services and regional competitiveness - Assessing drivers and mechanisms in nine European case study areas. Land Use Policy 76: 735-745. https://doi.org/10.1016/j.landusepol.2018.03.001

StancheVA, J. - BencheVA, S. - PetKova, K. - PiRalkov, V. (2006): Possibilities for agroforestry development in Bulgaria: Outlooks and limitations. ecological engineering 29: 382-387. https://doi.org/10.1016/j.ecoleng.2006.09.013

SZARVAS, P. (2010): Mezővédő erdősávok, fasorok jellemzése, ökológiai feltárása, kihatásai. [Characterization, ecological exploration and effects of field protection forest strips and tree lines] Doctoral thesis. Debreceni Egyetem. (in Hungarian)

SzÉL, Gy. - KÁDÁR, F. (2012): Futóbogár- együttesek vizsgálata a Lajta project területén. (Investigations of ground beetle assemblages in the Lajta Project (Mosonszolnok, W-Hungary.) In: Faragó S. (szerk.): A Lajta Project: Egy tartamos mezei vad és ökoszisztéma vizsgálat 20 éve. [The Lajta Project: 20 years of a long-term field wildlife and ecosystem study] Nyugatmagyarországi Egyetem Kiadó, Sopron. pp.: 244-269. (in Hungarian)

TAKÁCS, V. - FRANK, N. (2008): The traditions, resources and potential of forest growing and multipurpose shelterbelts in Hungary. In: Antonio Rigueiro-Rodróguez, Jim McAdam, Maria Rosa Mosquera-Losada (szerk.) Agroforestry in Europe: Current status and future prospects. 449 p. https://doi.org/10.1007/978-1-4020-8272-6 21

TAKÁCS, V. (2008): Útfásítások közlekedésbiztonsági vizsgálata a Sopron-Fertőd Kistérség területén. [Analysis of traffic safety of roadside afforestations in the Sopron-Fertöd region] Doctoral thesis, NyME, Sopron. (in Hungarian) 
TodD, J. H. - Poulton, J. - RichaRds, K. - MALONE, L. A. (2018): Effect of orchard management, neighbouring land-use and shelterbelt tree composition on the parasitism of pest leafroller (Lepidoptera: Tortricidae) larvae in kiwifruit orchard shelterbelts. Agriculture, Ecosystems and Environment 260: 27-35. https://doi.org/10.1016/j.agee.2018.03.016

TORITA, H. - SATOU, H. (2007). Relationship between shelterbelt structure and mean wind reduction. Agricultural and Forest Meteorology 145 (3-4): 186-194. https://doi.org/10.1016/j.agrformet.2007.04.018

TYNDALL J. C. (2009): Characterizing pork producer demand for shelterbelts to mitigate odor: An Iowa case study. Agroforest Syst 77: 205-221. https://doi.org/10.1007/s10457-009-9242-X

URL1: (http://www.agforinsight.com/?p=214) BEE

URL2: http://www.agforinsight.com/?p=371

VANDERMEER, J. (1989): The ecology of intercropping. Cambridge University Press, UK.

VERnON, C.Q. - GARDNER, J. - BRANDLE, J.R. - BOES, T.K. (1991): Windbreaks in Sustainable $\begin{array}{llllll}\text { Agricultural Systems. Papers in Natural Resources. } & 127 .\end{array}$ https://digitalcommons.unl.edu/natrespapers/127

WiLlis, W.B. -EICHINGER, W.E. -PRUEGER, J.H. -HAPEMAN, C.J. -LI, H. - BuSER, M.D. -HATFIELD, J.L. - WANJURA, J.D. - , Gregory A. Holt, G.A. - ToRRENTS, A. - PlenNER, S.J. - ClaridA, W. - BRowne, S.D. - DownEY, P.M., - YAO, Q. (2017): Particulate capture efficiency of a vegetative environmental buffer surrounding an animal feeding operation. Agriculture, Ecosystems and Environment 240: 101-108. https://doi.org/10.1016/j.agee.2017.02.006

WINKLER, D. (2012): A Lajta projekt herpetofaunája. [The herpetofauna of the Lajta project] In: Faragó S. (ed.): A Lajta Project: Egy tartamos mezei vad és ökoszisztéma vizsgálat 20 éve. [The Lajta Project: 20 years of a long-term field wildlife and ecosystem study] Nyugat-magyarországi Egyetem Kiadó, Sopron. pp.: 280-283. (in Hungarian)

WinKLER, D. - TRASER, GY. (2012): Collembola Diversity in Agricultural Environments (Lajta Project, Western Hungary). International Scientific Conference on Sustainable Development \& Ecological Footprint Sopron, Hungary March 26-27 2012.

WINKLER, D. - TRASER, GY. (2017): Talajlakó mezofauna (collembola) vizsgálatok a Lajta project területén. Hungarian Small Game Bulletin 13: 213-224. http://dx.doi.org/10.17243/mavk.2017.213

WIRÉHN, L. (2018): Nordic agriculture under climate change: A systematic review of challenges, opportunities and adaptation strategies for crop production. Land Use Policy 77: 63-74. https://doi.org/10.1016/j.landusepol.2018.04.059

Wu, P. - AXMACHER, J.C. - LI, X. - SONG, X. - YU, Z. - XU, H. - TsCARntKe, T. - WestPhal, C. LIU, Y. (2019): Contrasting effects of natural shrubland and plantation forests on bee assemblages at neighboring apple orchards in Beijing, China. Biological Conservation 237: 456-462. https://doi.org/10.1016/j.biocon.2019.07.029

XIE, H. - WANG, G. - YU, M. (2018): Ecosystem multifunctionality is highly related to the shelterbelt structure and plant species diversity in mixed shelterbelts of eastern China. Global Ecology and Conservation 16: e00470. https://doi.org/10.1016/j.gecco.2018.e00470

YANG, D. - LIU, W. - WANG, J. - LIU, B. - FANG, Y. - LI, H. - ZOU, X. (2018): Wind erosion forces and wind direction distribution for assessing the efficiency of shelterbelts in northern China. Aeolian Research 33: 44-52. https://doi.org/10.1016/j.aeolia.2018.05.001

ZAJĄCZKOWSKI, J. (2016): Ecosystem services by trees outside forest: should the structure and location of new plantings matter more? 3rd European Agroforestry Conference Montpellier, France, 23-25 May 2016 Book of Abstracts.

ZHENG, X. - ZHU, J. - XING, Z. 2016: Assessment of the effects of shelterbelts on crop yields at the regional scale in Northeast China. Agricultural Systems 143: 49-60. https://doi.org/10.1016/j.agsy.2015.12.008

Zhou, X.H. - BRANDLE, J.R. C MiZE, C.W. - TAKLE, E.S. (2004): Three-dimensional aerodynamic structure of a tree shelterbelt: Definition, characterization and working models. Agroforestry Systems 63: 133-147. https://doi.org/10.1007/s10457-004-3147-5

ZHU, J.-J. (2008): Wind Shelterbelts. Encyclopedia of Ecology, 3803-3812. https://doi.org/10.1016/b978-008045405-4.00366-9 